\title{
The Role of Slovenia in Stabilization, Integration and Security of Southeastern European Countries: Opportunities Missed
}

\author{
Jelena Juvan*
}

\begin{abstract}
Slovenia was first among the former Yugoslav countries to gain full membership in the EU and NATO. Today, Slovenia is considered a success story and a role model for Southeastern (SE) European countries ${ }^{1}$ aspiring for EU and NATO membership. In 1995, after the Balkan wars ended, the process of stabilization in the war-torn countries began. Slovenia saw an opportunity to use its historical advantages in comparison to other countries and appear as a prime mover for the stabilization and integration in the region. The article reflects on the effectiveness of Slovenia's foreign policy with regard to SE Europe. Slovenia does aspire to play a more active role in SE Europe. However, this does not seem to be the case in practice, for which Slovenia is also to be blamed. The article also identifies the most important regional initiatives in the field of security and opportunities for Slovenia to play a more active role in the region's security.
\end{abstract}

Keywords: Slovenia, Southeastern Europe, EU, security, cooperation

Slowenien, Südosteuropa, EU, Sicherheit, Kooperation

\section{Introduction}

$\mathrm{T}$ The geographic region of Southeastern Europe, also known as the Balkans, has always been of an exceptional importance for Slovenia, specially focusing on countries of the Western Balkans, or countries that were, together with Slovenia, once a part of a common country, the Socialist Federal Republic of Yugoslavia (Yugoslavia). Not only for historical, but also for geographic, economic and other reasons, Slovenia has always felt closer to this part of Europe, although during some periods in its history, it strived to get disconnected from this area. This can be noted for the period of the first decade after the breakup of Yugoslavia, when the priority of Slovenia's foreign policy was oriented towards the European Union (EU) and NATO, while trying to escape from the 'problematic Balkan'. It appeared as if the main efforts of the state's foreign policy during the aforementioned period were concentrated on trying to convince the EU's public that Slovenia has nothing to do with the 'barbaric' Balkan, in which people were killing themselves.

At the beginning of the new millennium, after Slovenia successfully gained full membership both in the EU and in NATO, which was set as foreign policy's most important priority after becoming an independent state, a foreign policy vacuum appeared, state's priorities shifted and Slovenia had to reconsider its main objectives. Furthermore, the problematic area of Western Balkans seemed close and appropriate, hoping the international community and the EU will recognize Slovenia's historical advantages; never minding a decade where Slovenia tried to escape from the Western Balkans.

Today, Slovenia aspires to play a stronger and more active role in the region and to achieve recognition as an important actor

* Jelena Juvan, PhD, is graduate research fellow at Faculty of Social Sciences, University of Ljubljana, Slovenia. Contact: jelena.juvan@fdv.uni-lj.si. This article has successfully undergone a double-blind peer-review process.

1 The geographic term of Southeastern European countries is used to designate the countries which became independent after the breakup of Yugoslavia in 1991, also known as the countries of the Western Balkans. in the field. However, there are some important issues to be considered. Is Slovenia as a state mature enough and capable to play such a role? Are the advantages of Slovenia, compared to other, perhaps more important actors in the international community, in solving problems connected with the countries of SE Europe so much greater? Is Slovenia's role as a mediator also acceptable by all the countries involved? These questions are especially important when taking into consideration Slovenia's historic role in the secession of Yugoslavia and the fact that Slovenia is by some countries in the region still considered to be the most responsible for the end of Yugoslavia and, consequently, also responsible for the armed conflicts that broke out in other former-Yugoslav republic after the disintegration of the common state. As Rahten $(2010,133)$ states: "Slovenia has a large potential role to develop into an important actor in the region under the auspices of the EU. However, the realisation of such ambitions does not depend only on Slovenia. The reason does not lay only in its demographic, economic and financial restrictions, but also in an increasing enterprise of other actors". Thus, without doubt Slovenia is facing serious competition to act as a saviour of the countries in the region aspiring for membership in EuroAtlantic integration.

\section{Slovenia after 1991}

Slovenia, as one of the six former Yugoslav republics, proclaimed its independence on June 26, 1991. On the morning following the announcement of independence, troops of the Yugoslav People's Army (YPA) left their barracks and marched towards the Slovenian international borders with neighbouring countries. The Presidency of Slovenia has agreed by common consent that the YPA was committing aggressive acts against the Republic of Slovenia, and all the precautions necessary, including the use of military forces of the territorial defence and the police, were immediately implemented (Prunk 2000, 227). What followed 
was a "10-day-war", with some severe engagements. Military operations of YPA were assisted by their air forces. Although the armed conflict lasted only 10 days and cannot be compared to the atrocities later in Croatia and Bosnia and Herzegovina, it was an armed conflict with victims: 39 soldiers killed and 139 wounded among the members of the YPA; 8 killed and 89 wounded on the Slovenian side. There were also 13 civilians killed, among whom were some foreign citizens killed during the air attacks (Prunk 2000, 230).

During the time of the armed conflict in-depth political and diplomatic efforts from the Slovenian authorities were going on with two-folded objectives. The first objective was to persuade the Yugoslav authorities and the commanding staff of the YPA to stop the military operations on the ground. The second was to inform the international community about the truth in the on-going conflict and gain the international recognition as an independent state. On July 7, 1991 diplomatic efforts achieved results. Meeting at the islands of Brioni in Croatia, the Slovenian delegation led by president Milan Kučan met with the Yugoslav delegation. The delegation from the European Community presided over the meeting (ibid.). A common declaration ${ }^{2}$ was signed, which effectively meant the end of the war. Although parts of the Slovene public and some members of the parliament believed that signing the declaration was a capitulation and negation of independence, on June 10, 1991 the declaration was ratified by the Slovene parliament (Prunk 2000, 231).

Despite the moratorium on the implementation of independence ${ }^{3}$, Slovenia continued its diplomatic activities. By September 25 it was recognized by Croatia, Lithuania, Georgia, Latvia and Estonia. After the expiration of the moratorium on October 8, 1991, all resolutions adopted on June 25 came into effect. The Parliament adopted several monetary measures and introduced the Slovene tolar as state currency (Prunk 2000, 231). On January 15, 1992 the European Community recognized Slovenia and Croatia. On May 22, 1992 Slovenia became a full member of the United Nations (Prunk 2000, 232), and in 2004 full member of the EU and NATO.

\section{Slovenia's Foreign Policy towards SE Europe}

As previously mentioned, in the first decade after the breakup of Yugoslavia and during the years when war was raging in neighbouring Croatia and Bosnia and Herzegovina, Slovenia was trying to escape this region. In 1999 a Declaration of Foreign Policy of Slovenia ${ }^{4}$ was adopted, and it can be noted how the region of the Western Balkans was, at that time,

2 The declaration stated that the Slovene police would control the borders of the republic and the taxes were to remain as income of the Yugoslav federation. The borders were to be returned to the state previous to June 25 th 1991, and the Slovene armed forces would lift the blockades from all the barracks. Slovenian Territorial defence forces were to be demobilized and all prisoners of war returned in 24 hours. Slovenia also had to agree to a 3-monthmoratorium on the implementation of its independence (Prunk 2000, 230).

3 See footnote 3 above.

4 The Declaration identifies Slovenia as a Central European state, which resembles the position at that time wishing not to have anything in common with the countries of the Western Balkans. The only objectives identified in respect to this region were in the field of the succession of the former common state Yugoslavia. not set as a national priority (Deklaracija o zunanji politiki Republike Slovenije). Also during the EU accession period, the Slovenian political elite exercised restraint regarding initiatives of international partners to assume a more active role in the region's developments. Not until the beginning of a new millennium ${ }^{5}$, and especially with the full membership in the EU and NATO, did Slovenia reinvent the Balkans as a foreign policy priority. It can be said that after the objectives of the full membership in the Euro-Atlantic structures were achieved, Slovenia's foreign policy has lost its compass, and thus tried to identify new foreign policy's goals and objectives. Assisting the other republics in achieving the same goals was already underway, and it seemed like a good opportunity. However, intentions of other players in the international community were not taken into account.

Rahten $(2010,140)$ noticed that Slovenia started assuming a more relaxed attitude towards the other republics when it became clear that Slovenia was going to join the EU in 2004. In the first half of 2008 Slovenia assumed the EU Council Presidency. One of the main objectives for a 6-month-presidency was to settle the unfinished business with Kosovo. Rahten $(2010,141)$ states that Slovenia played a double role. As a presiding country, it felt responsible to achieve unification for the positioning of all EU countries. On the other side, it could not avoid the fact that due to historical circumstances, its position differed from the positions of other countries.

Slovenia used its presidency of the EU Council as an opportunity to raise the Common EU Policy for Western Balkans up to the higher level on the EU agenda and simultaneously speed up the process of the region's integration in the EU. The presumption underlying this objective was that stability in the countries of the Western Balkans could only be reached by preserving and maintaining the perspective of EU enlargement alive. The majority of the countries do not have their own solid democratic tradition or a sufficient economy to help establish a stable base for solving internal interethnic conflicts (Bušljeta 2010, 76). During that time, as Bušljeta (ibid.) notices, no strong enthusiasm towards further EU enlargement was present among the EU member states, which also influenced countries of the Western Balkans. Slovenia wished to bring the issue of the Western Balkans' states back to the EU agenda (Program slovenskega predsedovanja Svetu EU: januar - julij 2008 ).

Prior to the presidency Slovenia has set its own national preferences in several areas: establishment of the regional market in respect to EU standards; less fragmentised developmental assistance and more transparent contribution for each country in the region strongly coordinated with other policies; and public diplomacy (Program slovenskega predsedovanja Svetu EU: januar - julij 2008; Bušljeta 2010, 77).

With the realisation of these preferences Slovenia wished to establish itself as a bridge towards the EU for the Western Balkans states, which would also strengthen the long-term political and economic ties with the region. On the other hand, with the successful performance in the region, Slovenia aspired

5 The first official programme document underlining the need for a more active role of Slovenia in the Western Balkans was adopted in 2002 (Rahten 2010, 140). 
to confirm its reputation as a connoisseur of the Western Balkans issues among other EU states. The issues of Kosovo and Serbia were identified as the main challenge during Slovenia's EU Council Presidency.

As main objectives to be reached during its 6-month-presidency Slovenia has set the signature of Stabilization and Association Agreements with the countries in the region, who have not yet signed the agreement (Serbia and Bosnia and Herzegovina) and to strengthen some areas of cooperation between the EU and the Western Balkans (transport, research and development, fellowships, civil protection) that have already been a part of the Thessaloniki Agenda ${ }^{6}$ (EU Western Balkans Summit).

The goals that were a priority during the Slovenian presidency were summarized in the following 5 points:

The successful ratification of the Lisbon Treaty: Slovenia had set a goal to ensure that the new Treaty would enter into force before the European Parliament elections in 2009. Slovenia itself has effectively ratified the Treaty in January 2008 in order to encourage other member states.

The Lisbon Strategy presented one of the key tasks of the Slovenian presidency, and in 2008 it entered the new three-year cycle of implementation. The results of the first period were already visible in increased growth and employment, thus, the continuation of the process was identified as crucial in order to achieve the objectives. Slovenia has focused its presidency on four priority areas of the Lisbon Strategy: investment in research, knowledge and innovation; development of a competitive business environment; labour market adjustment; and responses to demographic challenges and issues of energy and climate change.

Stability of the Western Balkans was the next key area representing a priority in the Slovenian presidency and, in its view, should remain a key item on the agenda of the EU. Slovenia will strive for reaffirmation of the Thessaloniki Agenda, which was signed in 2003, completing the network of Stabilisation and Association Agreements and the strengthening of regional cooperation in various fields.

The year 2008 was the year of the European Year of Intercultural Dialogue, therefore, Slovenia tried to strengthen the dialogue within the EU and has also promoted intercultural dialogue with the Western Balkans (Mlakar 2008, 53-55)

The analysis of Slovenia's EU Council Presidency shows (Bušljeta 2010, 113-114) that Slovenia has, in spite of the European Commission's powers, successfully managed to put its own initiatives on the agenda, e.g. the Transport Agreement with the Western Balkans. In the area of the EU's policy towards the Western Balkans, where other member states had no stronger national preferences, Slovenia has influenced the final outcome of the decisions according to its own national preferences, e.g. visa liberalization.

On the other hand, Bušljeta (ibid.) concludes that strong national interests and the unanimous decision-making process have limited and minimized the influence of Slovenia

6 EU Western Balkans Summit Declaration adopted on June the 21th 2003. as a presiding state. This can be confirmed by the Netherland's opposition to the Stabilisation and Association Agreement with Serbia ${ }^{7}$ and Greece's opposition to set the dates for starting the EU association negotiations with Macedonia ${ }^{8}$. During the presidency in March 2008 Slovenia organized a conference on the Western Balkans in order to initialize the so-called Brdo Process. The conference was an attempt to position Slovenia as important actor in the region, capable of solving crucial political conflicts in the region, with emphasizs given to solving the issue of Kosovo (Hribar, Geršak 2010). Intentions of the conference were extremely ambitious: to get all leaders of the countries of the Western Balkans to meet at one place for the very first time. However, the conference was a diplomatic fiasco even before it began. President of Serbia Boris Tadić refused to attend the conference because Kosovo as a state was also invited. Some prior agreements show that Serbia agreed to attend the conference only if Kosovo was to participate under the name of UNMIK. But, due to the pressure of the Kosovo delegation, this agreement was changed at last notice. European Council President Herman van Rompuy also refused to attend the conference. Officially, his schedule was busy. The absence of two very important politicians was not the only problem. Due to the aforementioned diplomatic complications other prominent European politicians did not attend the conference: European Commission President Jose Manuel Barroso; High Representative of the Union for Foreign Affairs and Security Policy Catherine Ashton; and the Spanish Prime Minister Jose Zapatero. ${ }^{9}$ Among the representatives of the EU only European Commissioner for Enlargement and Neighbourhood Policy Štefan Füle was present, however, he left the conference early, only half an hour after the conference's opening.

Slovenia's influence on the EU common policy towards the Western Balkans could be seen as insufficient but fundamental, or small yet positive (Bušljeta 2010, 114). However, Slovenia's influence faded away and was not preserved.

After Slovenia's EU Council Presidency was over Slovenia continued to play an active role in regard to the countries of the Western Balkans. This can be noted through the adoption of some national documents. In July 2010 the Slovene parliament adopted a declaration on the Western Balkans (Deklaracija o zahodnem Balkanu). The declaration states that Slovenia will continue to support and assist the Western Balkan states in their processes of accession to the EU.

A more "serious approach" was declared through the adoption of guidelines for the operation of Slovenia in regards to the Western Balkans by the government of Slovenia in July 2010 (Smernice za delovanje Republike Slovenije do zahodnega

7 During the period of Slovenia's EU Council Presidency the situation on Kosovo and Serbia has deteriorated, but Slovenia managed to gain some negotiating advancement and convince the Netherlands to agree to the Stabilization and Association Agreement with Serbia (Bušljeta 2010, 114).

8 In the case of Greece's opposition, Slovenia as a presiding state did not have any strong negotiating positions and in order to preserve good bilateral relations with Greece decided not to interfere in the conflict regarding the official name of Macedonia (Bušljeta 2010, 114). In the case of Macedonia, Slovenia estimated that its relations with Greece were more important than the status of Macedonia.

9 Spain was presiding the EU at that time. Since Spain is one of the EU countries not to recognize Kosovo as an independent state, no representatives from Spain were willing to attend the conference where Serbia and Kosovo did not attend as independent state. 
Balkana). This approach defined the priority areas and actions necessary for a more coherent and coordinated approach of all the regional entities, whether state, economic, or others. However, while the majority of previous actions of Slovenia regarding the Western Balkans have been taken in order to assist the countries from the region in joining the EU, this document is a manifest from a different point of view. Its objective is to create a favourable environment in the region in order to achieve successful representation and implementation of Slovenia's national interests. The security and stability of the region is undoubtedly in the interest of Slovenia.

In order to manifest a more serious and active foreign policy approach towards SE Europe, especially towards Bosnia and Herzegovina, in autumn 2010 the Slovenian prime minister has appointed Milan Kučan ${ }^{10}$ as a special envoy for Bosnia and Herzegovina (Žbogar: Kučan lahko kot posebni odposlanec v $\mathrm{BiH}$ da dodano vrednost kot politična osebnost). The main task of the special envoy was to identify possibilities for constitutional changes in Bosnia and Herzegovina. According to the conclusions ${ }^{11}$ of the special envoy, the government of Slovenia would develop its own standpoints to be presented at the European and international level.

\subsection{Slovenia's Relations towards Croatia}

Croatia is Slovenia's first neighbour to the South. Slovenia's relationship with Croatia has been problematic since the beginning of their independence. ${ }^{12}$ At the time of proclamation of independence several questions in bi-lateral relations, mainly concerning borders, were left open in order to be solved later. However, even twenty years later they still remain unsolved, escalating up to a point where Slovenia blocked Croatia's accession to the EU in 2009. It can be noted that open problems with Croatia have strongly influenced Slovenia's foreign policy towards its neighbouring countries as well as Slovenia's internal politics and relations between its main political parties. The situation with Croatia and the unresolved issues seem to be a very useful tool for challenging the political opponents during pre-election periods.

During the time of the former Yugoslavia, sea borders between the republics were not established. When Slovenia and Croatia proclaimed independence they still had to reach an agreement considering the demarcation in Piranski zaliv (bay of Piran). There was no room for negotiations concerning the issue of access to international waters, as this was of vital importance to the Slovenians. Croatia believes the demarcation line should run through the middle of the bay, which would mean the loss

10 Milan Kučan was the first president of Slovenia, from 1992 to 2002. After the end of his second mandate he stayed active in the politics and is considered a prominent opinion maker.

11 In December 2010 a report on Bosnia and Herzegovina was presented to the prime minister, however, the report was marked as confidential, and its conclusions were not made public. The report was also presented to the president of the EU Council Herman Van Rompuy. This annoyed the largest opposition party in Slovenia, which demanded an emergency session of the Parliamentary Foreign Policy Board (Odbor za zunanjo politiko se je seznanil s Kučanovim poročilom o $\mathrm{BiH}$ ). This session was also closed for media and the public.

12 Slovenia and Croatia have proclaimed independence on the same date, 25 June 1991. of access to open international waters for Slovenia, a position Slovenia is not ready to accept under any conditions. However, not only the issues of the sea border have aggravated relations between the two neighbouring countries: issues of repayment of foreign currency deposits of Croatia' savers in Ljubljanska bank $a^{13}$ and electricity from nuclear power plant Krško are still considered as open questions in the relations between Slovenia and Croatia (Dobre sosedske odnose med Slovenijo in Hrvaško že od osamosvojitve obeh držav leta 1991 kalijo nekatera nerešena vprašanja).

There have been several failed attempts from different political leaders over a 20-year period to try and achieve a satisfactory solution on both sides. A solution was almost agreed on in 2001, when the prime ministers of Slovenia and Croatia at that time, Drnovšek and Račan, have reached an agreement: the so-called "Drnovšek-Račan agreement", defining the seaborder between the two countries. However, this agreement was strongly rejected by the Croatian public and not ratified by the Croatian parliament. Therefore, it never became valid.

According to this agreement, 80 per cent of the Piranski zaliv would belong to Slovenia, gaining also the access to international waters. The "Drnovšek-Račan" agreement was accepted and ratified by the Slovenian parliament; but causes strong opposition on Croatia's side, which strongly believed that Piranski zaliv was to be divided in half. Following the refusal of the agreement, several serious incidents between boats of Slovene police and Croatian fishermen in the Piranski zaliv occurred, escalating in summer 2002. Consequently, both sides have agreed to sustain from further incidents and in 2007 the prime ministers of both countries, Janša and Sanader, have agreed to try to reach a solution with legal assistance. ${ }^{14}$

Currently, the issue concerning the sea border between the countries still remains a problem to be resolved with a pending decision by the arbitration tribunal. On November 4 , 2009, after several long-term negotiations, the governments of Slovenia and Croatia have signed an Arbitrary agreement binding themselves to respect the decision of the Arbitrary court regarding the sea border in Piranski zaliv (O sporazumu). Slovenia held a referendum regarding the acceptance of the Arbitrary agreement on June 6, 2010, resulting in the majority of 51,54 per cent accepting the Arbitrary agreement (Referendum).

At the end of 2009 Slovenia had blocked Croatia's accession to the EU again, in regard to three additional accession areas: fishing trade, environment, and foreign, security and defence policy (European Voice: Slovenija ponovno blokira Hrvaško).

13 Issues of repayment of foreign currency deposits of savers in Ljubljanska banka are not solely a problem of Croatian's savers, but of all non-Slovenian savers in the former Yugoslavia who have had their deposits in Ljubljanska banka at the time of the breakup (Dobre sosedske odnose med Slovenijo in Hrvaško že od osamosvojitve obeh držav leta 1991 kalijo nekatera nerešena vprašanja). The issue of deposits was included in negotiations on the succession of the former Yugoslavia, which ended in 2004 when the last republic ratified the agreement on succession. However, the issue of deposits is still to be solved under the negotiations of the Bank for international settlements (Bilateralno sodelovanje in vprašanja nasledstva SFRJ).

14 According to an agreement between Slovene PM Janez Janša and Croatian PM Ivo Sanader, which was reached in August 2007, issues of borders were to be solved with legal assistance. A mixed Slovenian-Croatian commission of legal experts was established; however, no significant progress was achieved (Zgodovina reševanja vprašanja meje). 
In February 2011 the president of the EU parliament Jerzy Buzek complimented Croatia on the progress achieved in its accession to the EU. He also warned, however, that issues between Slovenia and Croatia have to be resolved prior to Croatia's full admission to the EU (Buzek: Vprašanja med Hrvaško in Slovenijo morajo biti rešena pred širitvijo). On June $10^{\text {th }} 2011$ president of the European Commission Jose Manuel Barroso suggested closing the accession talks with Croatia. This was confirmed by the European Council on June $24^{\text {th }} 2011$, which has also called for the signature of the Accession agreement with Croatia by the end of 2011 (EU Summit: Accession Treaty with Croatia to be signed in 2011). Prime minister of Slovenia Borut Pahor has praised this decision of the European Council and congratulated the Croatian government. According to him, Slovenia has, in negotiations with Croatia, "practically resolved all open question, or at least has agreed on the methods for solving them" (Pahor o vstopu Hrvaške v EU: Izjemno pomembna odločitev za Hrvaško, regijo in EU).

\section{Conclusion}

Slovenia does have some advantages compared to other EU states in relations to the countries of the Western Balkans. Historical ties with this region and language similarities are just some of those advantages. The historical memory of a common Yugoslav country is still alive and rather strong, especially among the older generations. However, as decades are passing by, the historical memory will fade away, generations of people who once lived in a common country will die, and the advantage of Slovenia as a former "brother republic" will be completely gone. Therefore, an active role of Slovenia in the region should also be based on some other foundations and not only on historical ties. The main question here is what those foundations are?

Rahten $(2010,140)$ believes that Slovenia cannot play a key role in the Western Balkans just because of its commonality in history and language. Other countries must be taken into account when concerning the different factors and circumstances. While some of the largest European countries are represented in the region, also other European countries have increased their influence in the region, such as Austria and Slovakia. In order to play a more active regional role, undoubtedly, all disputes between Slovenia and Croatia have to be resolved first. Unresolved issues with its neighbouring country raise serious doubts whether or not Slovenia is capable of playing a more active role in the region, since it hasn't been capable of solving a dispute with Croatia over "a few kilometres" of border during a 20-year period.

In 2011 Slovenia is celebrating the 20th anniversary of its independence. The two main foreign policy objectives, joining the EU and NATO, were successfully reached. The state has become more experienced but still lacks a strong foreign policy, such as identifying and defending national interests and becoming a leading regional player. Now it is time to set new priorities, although the state and its leaders seem to have problems with this. Putting the region of the Western Balkans ahead of national objectives is a legitimate goal; however, it seems that Slovenia has chosen this priority not because of its true and honest desires to help the countries of the region, but because of its selfish intentions to show the rest of the Europe what Slovenia is capable of, or what it thinks it is capable of, while neither Europe nor the countries of the region recognize this ability.

\section{Bibliography}

Bilateralno sodelovanje in vprašanja nasledstva SFRJ [Bilateral cooperation and the issues of the Yugoslav succession]. http://www. mf.gov.si/si/delovna_podrocja/mednarodni_financni_odnosi/ bilateralno_sodelovanje_in_vprasanja_nasledstva_sfrj/. 29.6.2011.

Bušljeta, Nataša. 2010. Vpliv slovenskega predsedstva Sveta Evropske unije na oblikovanje skupne politike Evropske unije do Zahodnega Balkana [Impact of the Slovene Presidency to the Council of the European Union on the formation of the Common European Policy on the Western Balkans]. Ljubljana: FDV, master thesis.

Buzek: Vprašanja med Hrvaško in Slovenijo morajo biti rešena pred širitvijo. (Buzek: Issues between Croatia and Slovenia have to be resolved prior the enlargement]. 2011. http://www. rtvslovenija.si/evropska-unija/buzek-vprasanja-med-hrvaskoin-slovenijo-morajo-biti-resena-pred-siritvijo/251020, 25.5. 2011.

Deklaracija o zahodnem Balkanu [Declaration on the Western Balkans]. 2010. http://www.uradni-list.si/1/content?id=99131, 2.2.2011.

Deklaracija o zunanji politiki Republike Slovenije [Declaration on Foreign Policy of Slovenia]. 1999.http://www.mzz.gov.si/si/ zakonodaja_in_dokumenti/podzakonski_akti/deklaracija_o_ zunanji_politiki_republike_slovenije/, 2.2.2011.

Dobre sosedske odnose med Slovenijo in Hrvaško že od osamosvojitve obeh držav leta 1991 kalijo nekatera nerešena vprašanja. [Good relations between Slovenia and Croatia are being aggravated by some unresolved issues since 1991]. http://www. rtvslo.si/zgodbe/slovenija/slovensko-hrvaski-odnosi/10, 25.5. 2011.

EU Western Balkans Summit: Declaration.2003. http://www. consilium.europa.eu/ueDocs/cms_Data/docs/pressdata/en/ misc/76291.pdf, 07.02.2011.

EU Summit: Accession Treaty with Croatia to be signed in 2011. http://www.eu2011.hu/news/eu-summit-accession-treatycroatia-be-signed-2011, 29.6.2011.

European Voice: Slovenija ponovno blokira Hrvaško [European Voice: Slovenia is again blocking Croatia]. http://www.finance. si/266616/European-Voice-Slovenija-ponovno-blokiraHrva\%B9ko, 25.5.2011.

Hribar, Matjaž in Katja Geršak. 2010. Stalna in neprekinjena pozornost. [Constant and continuous attention] Dnevnik, 3. april 2010. 
Mlakar, Mateja. 2008. Vloga Slovenije pri vključevanju Hrvaške $\mathrm{v}$ evropske integracijske tokove [Slovenian Contribution to European Integration Process in Croatia]. FDV. Ljubljana, master thesis.

Odbor za zunanjo politiko se je seznanil s Kučanovim poročilom o BiH. [Parliamentary Foreign Policy Board became familiar with the Kučan's report on BiH] http://www.siol.net/slovenija/ novice/2011/03/ozp_obravnava_kucanovo_porocilo_o_bih. aspx, 29.6.2011.

O sporazumu [On Agreement]. 2011.

http://www.vlada.si/si/teme_in_projekti/arbitrazni_sporazum/ o_sporazumu/, 25.5.2011.

Pahor o vstopu Hrvaške v EU: Izjemno pomembna odločitev za Hrvaško, regijo in EU. [Pahor on Croatia's accession to the EU: An extremely important decision for Croatia, for the region and for Slovenia]. http://www.dnevnik.si/novice/aktualne_ zgodbe/1042454660. 29.6.2011.

Program slovenskega predsedovanja Svetu EU: januar - julij 2008 [Programme of the Slovenian Presidency of the EU Council, Januar - July 2008] http://www.eu2008.si/includes/Downloads/ misc/program/Programme_si.pdf.

Prunk, Janko. 2000. A Brief History of Slovenia. Založba Grad, Ljubljana.

Rahten, Andrej. 2010. Slovenia and EU Policy in the Western Balkans - a Historian's Perspective. Bilten Slovenske Vojske, 12 (2), pp.133 - 144.

Referendum [Referendum]. http://www.vlada.si/si/teme_in_ projekti/arbitrazni_sporazum/referendum/, 25. maj 2011.

Slovenija in Hrvaška sta pri Generalnem sekretarju OZN registrirali Arbitražni sporazum [Slovenia and Croatia have registrated at UN General Secretary an Arbitration Agreement]. http://www.mzz. gov.si/nc/si/splosno/cns/novica/article/6/28898/1b7eb7fa10/, 26.5.2011.

Smernice za delovanje Republike Slovenije do Zahodnega Balkana [Guidlines for the operation of Slovenia to the Western Balkans]. 2010. http://www.mzz.gov.si/fileadmin/pageuploads/ Novinarsko_sredisce/Sporocila_za_javnost/1007/Smernice_ ZB.pdf, 2.2.2011.

Zgodovina reševanja vprašanja meje [The history of solving the border issues]. http://www.vlada.si/si/teme_in_projekti/ arbitrazni_sporazum/zgodovina_resevanja_vprasanja_meje/. 29.6.2011.

Žbogar: Kučan lahko kot posebni odposlanec v BiH da dodano vrednost kot politična osebnost [Žbogar: Kučan as a Special Envoy Has Added Values as a Political Personality]. 2010. http://www. dnevnik.si/novice/slovenija/1042402072, 25.5.2011.

\section{Die Politik-Plattform}

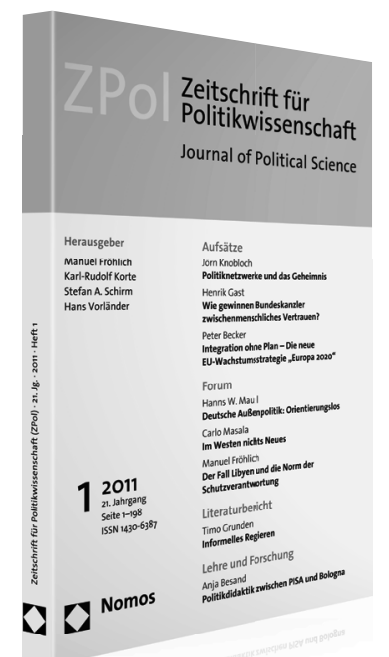

\section{Zeitschrift für Politikwissenschaft (ZPol)}

Journal of Political Science

21. Jahrgang 2011, erscheint $4 \times$ jährlich

ISSN $1430-6387$

Miniabo (2 Ausgaben): 19,- $€^{* *}$

inkl. Vertriebskosten und Porto

${ }^{* *}$ Wenn Sie die ZPol auch in Zukunft lesen möchten, brauchen Sie nichts zu veranlassen. Sie erhalten die Zeitschrift nach Ablauf des Miniabonnements dann regelmäßig zum Jahresabopreis.

\section{Jahresabo: $94,-€^{*}$}

Gesamtpreis: 105,03€

Vorzugspreis für Studierende, Mitglieder der DVPW, DGfP, DVParl, DVPB: 49,- $€^{*}$

(bitte Bescheinigung zusenden) Gesamtpreis: 60,03€

Jahresabo mit Online-Zugang - nur Aufsätze -: 113,- - $€^{*}$ (nur Privatbezieher) Gesamtpreis: 124,03€

*inkl. MwSt. zzgl. Vertriebskosten (€ 11,03/Jahr) (Porto/Inland € 9,42 + Direktbeorderungsgeb. $€ 1,61$ )

Die ZPol versteht sich als Forum für die gesamte Politikwissenschaft, für alle Teildisziplinen, Ansätze und Richtungen des Fachs. Als gemeinsames Band stehen die Grundlagen-, Theorie- und Praxisorientierung der Beiträge im Vordergrund. Neben begutachteten Aufsätzen finden sich im „Forum“ Analysen und pointierte Bewertungen aktueller, politikwissenschaftlich relevanter Themen sowie Platz für die wissenschaftliche Debatte und kritische Diskussion. Die Rubrik ,Lehre und Forschung" dient der Selbstverortung des Fachs in den Zeiten des Post-Bologna-Prozesses. Literaturberichte aus den verschiedenen Teildisziplinen der Politikwissenschaft vervollständigen die Zeitschrift.

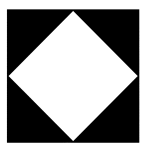

Nomos

Bitte bestellen Sie im Buchhandel oder versandkostenfrei unter $\triangleright$ www.nomos-shop.de 